Reynir Arngrímsson, MD, PhD

Professor of Clinical Genetics/Genetic Medicine, University of Iceland Dept. Genetics and Molecular Medicine

Landspítali University Hospital, 101 Reykjavík

President of the Icelandic Medical Association

https://doi.org/10.17992/lbl.2018.01.166

R I T S T J Ó R N A R G E I N erfðalæknir á L andspítala

formaður Læknafélags Íslands

\title{
Landinu og læknum til gagns og blessunar í 100 ár
}

Læknafélag Íslands var stofnað 14. janúar 1918 og heldur upp á 100 ára afmæli sitt í mánuðinum. Stofnfélagar voru 34. Í fyrstu stjórn félagsins voru kosnir Guðmundur Hannesson, Guðmundur Magnússson og Sæmundur Bjarnhéðinsson. Varamaður í stjórn var Matthías Einarsson. Frá Vestfirðingafjórðungi Halldór Steinsen, 1 Norðlendingafjórðungi Steingrímur Matthíasson, í Austfirðingafjórðungi Georg Georgsson. Í Læknablaðinu frá pessum tíma má lesa:

„Um pað skal engu spád, hversu félagi voru farnast, hvert gagn pað getur unnið bæði læknastéttinni og landinu, en eins dæmi væri pað áreiðanlega, ef pað yrði ekki báðum til gagns og blessunar. Í öllum menningarlöndum hafa læknar komið á fót föstum félagsskap og skipulagi sín á milli, og fleiri eða færri málgögnum til að ræða sín mál. Og hvervetna, undantekningarlaust, að eg hygg, hefir petta komið að bestu notum. Ólíklegt er pað, að vér verðum eina undantekningin, að oss gefist betur sundrung og sinnuleysi en "organisation" og áhugi.

Mitt í öllum harðindunum, prátt fyrir alla dýrtíð og styrjöld, byrja nú íslenskir læknar árið með pessari félagsstofnun, villausir og alls ósmeikir, til pess að búa betur í haginn fyrir komandi ár.

Illviðri og hvers konar óáran bitnar ekki síst á íslenskum læknum og engir sjá meira af hvers konar eymd og volæði. Deir hafa pó ekki gugnað til pessa, og eitthvað meira mun purfa til pess að draga úr peim kjarkinn en pessi illviðri og óáran, sem nú gengur yfir."1

Um árangur íslenskra lækna og frumkvæði peirra við skipulagningu heilbrigðispjónustunnar á peim 100 árum sem liðin eru parf vart að fjölyrða. Grunnmenntun í læknisfræði hafa flestir læknar fengið í læknadeild HÍ sem í öllum samanburði stendur jafnfætis pví sem best gerist og ber glöggt vitni um framsýni forystumanna í læknastétt. Framhaldsmenntun hafa læknar sjálfir purft að kosta og skipuleggja erlendis allt fram á pennan dag og nú að nokkru leyti hérlendis. Pannig má fullyrða að eigið framtak, frumkvæði og áræði íslenskra lækna á síðastliðnum hundrað árum hafi stuðlað аð heilbrigði pjóðarinnar eins og við pekkjum pað í dag.

Að tryggja viðunandi mönnun lækna er viðkvæmt ferli og lítið má út af bera ef tryggja á landsmönnum grunnheilbrigðispjónustu. Skammsýnar ákvarðanir stjórnvalda og stjórnenda heilbrigðisstofananna án aðkomu og faglegrar samvinnu við lækna og félaga peirra er hættuleg próun. Ábendingar Embættis landlæknis og
Umboðsmanns Alpingis og niðurstöður dómsmála í mannauðsmálum helstu heilbrigðisstofnana landsins sem lúta meðal annars að stjórnsýslu peirra gagnvart læknum, eru áhyggjuefni. Ekki síður viðbrögð stjórnendanna við pessum áfellisdómum. Pví miður verður ekki komist hjá pví að nefna petta á pessum tímamótum pví fram til pessa hefur lengst af á peim 100 árum sem LÍ hefur staðið vörð um hagsmuni lækna og stuðlað að framförum á landsvísu í heilbrigðismálum og eflingu sjúkrastofnana ríkt gagnkvæmt traust á milli lækna og stjórnvalda og ef sagan hefur kennt okkur eitthvað pá hefur pað verið pjóðinni til gagns og blessunar.

Stofnun Lí bar upp á frostaveturinn mikla pegar mesta frost sem vitað er um á landinu mældist, $-34,5$ stig. Petta var árið sem Katla gaus og spænska veikin varð heimsfaraldur og Ísland varð fullvalda. Í Reykjavík veiktust um 63\% íbúa og á fyrstu 6 vikunum frá pví hún barst til landsins höfðu tæplega 500 manns látist. Dánarhlutfall var hæst á meðal ungra barna, fólks á aldrinum 2040 ára og aldraðra. Einnig urðu barnshafandi konur illa úti. ${ }^{2}$

рað var pví vel við hæfi að afmælisnefnd LÍ valdi að læknirinn og umhverfið yrði pema afmælisársins 2018. Áhrif loftslagsbreytinga á heilsufar og lífsviðurværi mannkyns snertir lækna og allan almenning og bregðast verður við pessari umhverfisvá. Umræður og skilningur er grundvöllur aðgerða. Í janúar býðst læknum og almenningi að taka pátt í afmælisdagskrá í Hörpu pann 15. janúar næstkomandi par sem fjallað verður um petta efni frá sjónarhorni lækna.

Við endurskoðun Genfar-yfirlýsingar lækna síðasta haust var sampykkt að bæta við grein um mikilvægi pess að læknar sinntu heilsu sinni og heilbrigði í lífsháttum. ${ }^{3}$ Trú pessum tilmælum Alpjóðalæknasamtakanna og til eflingar félagsanda og samtakamáttar verður fjölbreytt gleðidagskrá fyrir lækna og fjölskyldur peirra allt afmælisárið eins og sjá má á öðrum stað í blaðinu. Ég óska læknum öllum til hamingju með sitt síunga félag, megi pað verða peim og landinu áfram til gagns og blessunar.

\section{Heimildir}

1. Hannesson G. Læknafélag Íslands. Læknablaðið 1918; 4: 1-2.

2. Gottfreðsson M. Spænska veikin á Íslandi 1918. Lærdómur í læknisfræði og sögu. Læknablaðið 2008; 94: 737-45.

3. World Medical Association Declaration of Geneva. wma.net/policies-post/wma-declaration-of-geneva/ - desember 2017. Sjá íslenska pýðingu Genfar-yfirlýsingarinnar á blaðsíðu 46 í pessu tölublaði. 